\title{
Rancang Bangun Sistem Pemisah Air - Minyak Berbasis Metode Adsorpsi Menggunakan Mikrokontroler Teensy
}

\author{
Bagus Aris Saputra, Muhammad Rivai, dan Tasripan \\ Departemen Teknik Elektro, Fakultas Teknologi Elektro, Institut Teknologi Sepuluh Nopember (ITS) \\ e-mail:Muhammad_rivai@ee.its.ac.id
}

\begin{abstract}
Abstrak - Limbah yang dihasilkan industri sering kali dibuang ke laut tanpa adanya pengolahan terlebih dahulu. Selain itu, kecelakaan kerja sering terjadi di perusahaan lepas pantai yang bergerak di bidang perminyakan, seperti terjadinya kebocoran pipa, tumpahnya minyak yang dibawa dan tenggelamnya kapal pembawa minyak tersebut. Adanya lapisan minyak tersebut dapat mengganggu keberlangsungan hidup biota laut. Pada penelitian ini telah dirancang suatu sistem yang dapat memisahkan air dan minyak berbasis metode adsorpsi atau penyedotan dan dilakukan secara otomatis yang ditempatkan pada suatu prototipe kapal. Sistem ini memanfaatkan komponen optik menggunakan laser dan light dependent resistor (LDR) untuk mengukur ketebalan minyak dan pompa hisap untuk mengambil minyak tersebut. Laju pompa hisap dikendalikan berdasarkan ketebalan minyak menggunakan kontrol proporsional. Mikrokontroler yang digunakan pada sistem ini yaitu Teensy yang memiliki ukuran yang cukup ringkas. Hasil pengujian menunjukkan bahwa tingkat keberhasilan sistem untuk menyedot minyak dari permukaan air mencapai $86 \%$. Sistem ini diharapkan dapat diimplementasikan pada ASV (Autonomous Surface Vehicles) sebagai salah satu metode untuk melakukan pembersihan laut dari tumpahan minyak secara otomatis.
\end{abstract}

Kata kunci-Ketebalan minyak, Kontrol proporsional, Laser, LDR, Mikrokontroler Teensy.

\section{PENDAHULUAN}

$\mathrm{S}_{\mathrm{b}}^{\mathrm{E}}$ EMAKIN berkembangnya berbagai perusahaan pada bidang industri, semakin berkembang pula limbah yang dihasilkan. Limbah merupakan barang atau benda sisa dari kegiatan produksi sehingga limbah tidak memiliki manfaat dan nilai lagi. Limbah sendiri dapat berupa padat, cair, maupun gas. Sering kali limbah tersebut tidak diolah terlebih dahulu sebelum dibuang sehingga dapat membahayakan organisme lain. Salah satu pembuangan limbah yang berbahaya yaitu limbah cair industri yang mengandung zat kimia berbahaya ke laut. Selain limbah industri, perusahaan yang bergerak di bidang perminyakan atau pengolahan sumber daya alam lepas pantai terkadang mengalami kecelakaan kerja yaitu kebocoran pipa, tumpahnya minyak yang dibawa dan tenggelamnya kapal pembawa minyak tersebut. Seperti pada tahun 2018, terjadi kebocoran pipa PT Pertamina (Persero) yang menyebabkan 12 ribu hektare perairan di Teluk Balikpapan tercemar oleh minyak [1]. Walaupun tidak dapat menyatu dengan air, minyak yang berada di laut memiliki potensi kerusakan yang besar terhadap ekosistem laut [2]. Efek dari limbah atau tumpahan minyak di laut yang dapat dilihat dalam jangka pendek yaitu matinya organismeorganisme laut karena teracuni minyak tersebut. Untuk jangka panjang, adanya minyak akan mempengaruhi sistem reproduksi dan tingkah lakunya, bahkan hilangnya populasi akan terjadi jika hal seperti ini terus terjadi.

Dengan adanya masalah tersebut, perkembangan teknologi yang bekerja di perairan sangat pesat. Salah satunya yaitu perkembangan ASV (Autonomous Surface Vehicle) yang merupakan kapal yang dapat bekerja otomatis tanpa awak. Tujuan dari ASV sendiri dapat dirancang sesuai kebutuhan penggunanya, seperti ASV yang dapat memantau kondisi perairan dari bahaya yang ditimbulkan gas beracun [3]. Penggunaan ASV tentunya dapat dikembangkan lagi dengan berbagai tujuan lainnya, seperti dalam masalah tumpahan minyak di laut.

Pada penelitian ini dirancang suatu sistem yang dapat memisahkan air dan minyak berbasis metode adsorpsi atau penyedotan dan dilakukan secara otomatis yang ditempatkan pada suatu prototipe kapal, agar kadar minyak di laut dapat dikurangi bahkan dihilangkan. Sistem ini memanfaatkan sensor optik untuk memantau ketebalan minyak, lalu digunakan pompa hisap untuk menghisap minyak yang berada pada permukaan air. Sensor optik yang dapat dimanfaatkan berupa laser dan LDR (Light Dependent Resistor). Laser berfungsi sebagai sumber cahaya dan LDR akan menerima cahaya tersebut untuk mengetahui ketebalan minyak. Semakin tebal lapisan minyak, maka intensitas cahaya yang diterima laser akan semakin kecil karena minyak memiliki serapan yang besar terhadap cahaya, sedangkan air memiliki serapan yang rendah [4]. Pompa hisap dapat memanfaatkan motor yang dikendalikan menggunakan kontrol proporsional untuk menghisap minyak dari permukaan air. Mikrokontroler yang digunakan adalah Teensy yang merupakan salah satu mikrokontroler terbaru. Dengan performa mikrokontroler yang lebih cepat maka sistem diharapkan dapat bekerja dengan baik. Teensy berperan sebagai pengatur sistem dengan mengatur laju pompa hisap berdasarkan ketebalan minyak. Saat lapisan minyak tergolong tebal, pompa akan menghisap dengan cepat. Namun seiring menipisnya lapisan minyak, laju pompa akan turun dan pada akhirnya akan mati saat tidak terdapat lapisan minyak. Sistem seperti ini diharapkan dapat diimplementasikan pada ASV sehingga upaya dalam mengatasi tumpahan minyak dapat dilakukan secara cepat dan otomatis. 


\section{DASAR TEORI}

\section{A. Komponen Optik}

Komponen optik yang digunakan pada penelitian ini berupa laser dan sensor optik, Light Dependent Resistor (LDR). Laser digunakan sebagai sumber cahaya, sedangkan LDR digunakan sebagai sensor optik yang mengubah nilai intensitas cahaya yang diterima menjadi satuan listrik.

Laser atau Light Aplification by Stimulated Emission of Radiation merupakan proses pancaran cahaya yang terstimulasi sehingga memancarkan cahaya yang kuat. Keuntungan menggunakan laser yaitu cahaya yang dihasilkan memiliki berkas cahaya yang kecil tetapi sangat terarah, serta intensitas yang tinggi. Cahaya yang dipancarkan laser menunjukkan panjang gelombang tunggal yang dapat dikenali dari frekuensi yang sama, beda fase yang konstan dan polarisasinya [5]. Panjang gelombang tunggal (satu warna) yang dihasilkan diperoleh dari pancaran foton pada arah yang sempit.

Light Dependent Resistor merupakan suatu resistor yang nilai resistansinya bergantung pada cahaya yang diterima. Nilai resistansi LDR semakin besar apabila intensitas cahaya yang diterima lebih kecil. LDR biasa digunakan untuk mendeteksi intensitas cahaya dengan cara energi cahaya berupa intensitas cahaya menjadi energi listrik berupa tegangan. LDR terbuat dari bahan semikonduktor yaitu dengan senyawa Cadmium Sulfide (CdS). Dengan bahan tersebut, semakin banyak LDR menerima cahaya maka semakin banyak pula muatan yang dilepas sehingga nilai resistansi akan menurun.

\section{B. Mikrokontroler Teensy}

Teensy merupakan sebuah microcontroller development board yang dikembangkan oleh Paul Stoffregen dan PJRC. Teensy memiliki ukuran yang tergolong kecil sehingga mikrokontroler ini tidak banyak menghabiskan ruang jika digunakan pada suatu sistem atau alat [6] - [8]. Pemrograman pada Teensy dapat dilakukan menggunakan kompiler bahasa $\mathrm{C}$ atau Arduino IDE dengan plugin Teensyduino. Berbagai library di Arduino juga dapat diimplementasikan pada mikrokontroler Teensy.

\section{Kontrol PID}

Kontrol Proportional - Integral - Derivative (PID) merupakan suatu kontroler umpan balik dengan cara menghitung nilai kesalahan antara nilai yang diinginkan (setpoint) dengan nilai yang terukur pada sistem. Kontrol PID dibutuhkan pada berbagai sistem instrumentasi untuk mencapai tujuan atau nilai yang diinginkan dengan memperbaiki nilai kesalahan secara terus-menerus.

Kontrol PID terdiri dari tiga parameter, yaitu proportional (P), Integral (I) dan derivative (D). Setiap parameter memiliki fungsi sebagai berikut [9]:

1. Proportional $(\mathrm{P})$ berfungsi untuk memperbaiki rise time dan settling time

2. Integral (I) berfungsi untuk memperbaiki respon steady state

3. Derivative (D) berfungsi untuk memperbaiki respon transien
Transfer function sistem yang menggunakan kontrol PID memiliki persamaan seperti persamaan (1).

$$
u(t)=K_{p} \cdot e(t)+K_{i} \cdot \int_{0}^{t} e(\tau) d \tau+K_{d} \cdot \frac{d e(t)}{d t}
$$

Dalam menentukan besar dari nilai $\mathrm{Kp}$, Ki dan $\mathrm{Kd}$, dapat dilakukan dengan cara tuning secara manual atau menggunakan berbagai metode tuning lainnya seperti metode Ziegler-Nichols [10], [11].

\section{Diaphragm Pump}

Diaphragm Pump atau pompa diafragma merupakan pompa yang bekerja secara bolak-balik untuk menghisap dan mendorong air dari ruang pompa. Pada saluran masuk pompa terdapat katup atau membran yang menjaga agar air mengalir sesuai pada salurannya. Untuk menghisap atau mendorong air, diafragma pada pompa perlu digerakkan. Prinsip kerja pompa diafragma ditunjukkan pada Gambar 1. Pompa ini banyak digunakan di berbagai industri yang membutuhkan alat untuk menghisap dan mendorong air, salah satunya seperti dalam menangani limbah industri.

\section{PERANCANGAN SISTEM}

Perancangan sistem ini menjelaskan sistem secara keseluruhan yang meliputi perangkat keras, perangkat mekanik dan perangkat lunak. Perangkat keras yang digunakan pada sistem ini meliputi sensor optik (laser dan LDR), mikrokontroler Teensy, LCD, driver motor, diaphragm pump dan tangki. Perangkat mekanik yang dirancang berupa akuarium berukuran kecil yang merepresentasikan sistem jika diimplementasikan pada sebuah ASV. Perangkat lunak yang diimplementasikan pada sistem berupa pembacaan sensor optik, smoothing, kontrol proportional dan kendali diaphragm pump.
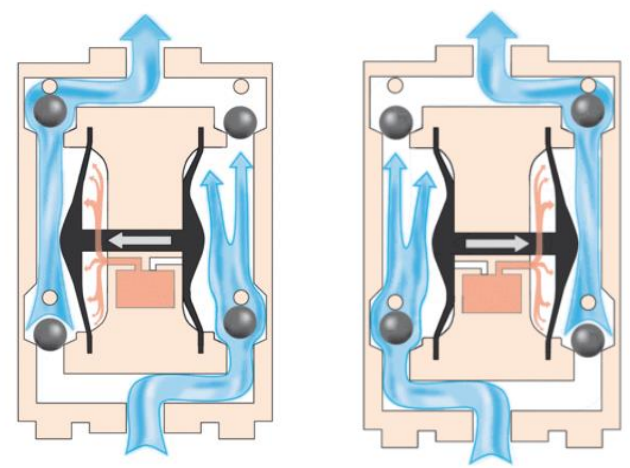

Gambar 1. Prinsip kerja diaphragm pump.

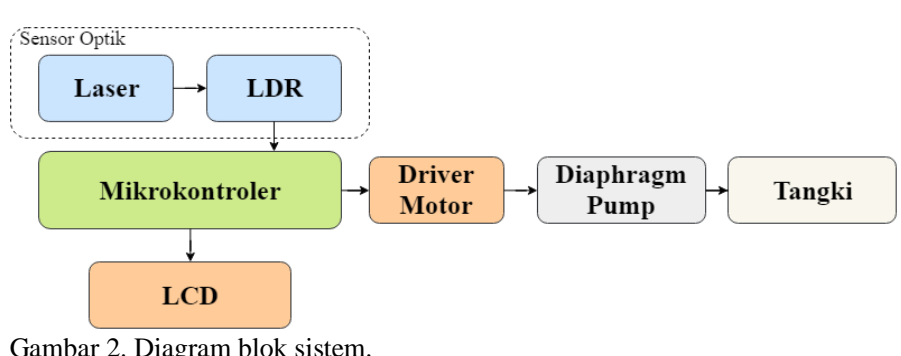

Gambar 2. Diagram blok sistem. 
Pada Gambar 2 menunjukkan diagram blok sistem pemisah air-minyak. Sensor optik terdiri dari laser dan LDR dimana laser berfungsi sebagai sumber cahaya dan LDR yang menerima cahaya tersebut. Data intensitas cahaya yang diterima LDR dikirimkan ke mikrokontroler melalui ADC sebagai input sistem. Mikrokontroler mengolah data tersebut untuk menentukan nilai PWM yang akan dikirimkan ke driver motor untuk mengatur laju diaphragm pump serta menampilkan parameter input dan output melalui LCD untuk memantau kerja sistem.

Perangkat keras sistem pemisah air-minyak :

1. Sensor Optik berfungsi untuk mengukur intensitas cahaya laser yang diterima LDR untuk mengetahui keberadaan serta ketebalan minyak di air.

2. Mikrokontroler Teensy berfungsi untuk menjalankan program sistem pemisah air-minyak. Data pengukuran sensor optik diolah untuk menentukan nilai PWM driver motor dan menampilkan data tersebut melalui LCD.

3. Driver Motor berfungsi untuk mengatur laju diaphragm pump sesuai dengan nilai PWM yang diterima dari mikrokontroler.

4. Diaphragm Pump berfungsi untuk mengisap minyak yang berada di permukaan air.

5. LCD berfungsi untuk menampilakn parameter input berupa tegangan dari sensor optik dan output berupa nilai PWM yang digunakan untuk mengatur laju diaphragm pump.

6. Tangki berfungsi untuk menampung minyak yang dihisap sistem menggunakan diaphragm pump.

Perangkat lunak sistem pemisah air-minyak dijalankan menggunakan mikrokontroler Teensy. Mikrokontroler menerima input sensor optik berupa intensitas cahaya yang diubah menjadi tegangan. Dari input tersebut, data diolah untuk menentukan nilai PWM driver motor untuk mengatur laju diaphragm pump.

Perancangan Mekanik

Pada penelitian ini, sistem diuji pada suatu wadah berupa ruang pengujian. Desain akurium dirancang seperti pada Gambar 3. Laser memancarkan cahayanya dari bawah ruang yang merepresentasikan laser berada di dalam air jika diimplementasikan pada ASV. Untuk rangkaian lainnya berada diatas ruang yang merepresentasikan rangkaian lain pada sistem berada di ASV. Setelah sistem diuji pada wadah, maka dilakukan pengujian dengan mengimplementasikan sistem pada suatu prototipe kapal seperti yang ditunjukkan pada Gambar 4. Seluruh rangkaian diletakkan pada permukaan kapal yang ditandai dengan warna merah dan hijau.

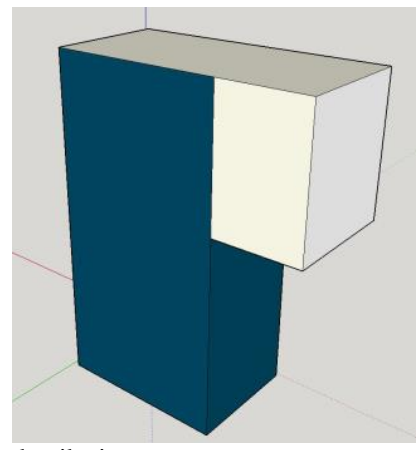

Gambar 3. Desain mekanik sistem.
Perancangan Perangkat Lunak

Pada perancangan perangkat lunak hanya menggunakan Teensy untuk melakukan pembacaan sensor optik, mengendalikan diaphragm pump dan kontrol proportional. Perancangan perangkat lunak secara keseluruhan ditunjukkan pada Gambar 5.

Pembacaan Sensor Optik

Pembacaan sensor optik digunakan untuk mengambil data intensitas cahaya yang diterima LDR melalui pin ADC Teensy. Rentang nilai sensor tersebut antara $0-1023$. Nilai sensor yang diterima akan dikonversi menjadi tegangan dengan rentang nilai $0-5$ volt, karena parameter yang digunakan untuk mengetahui ketelaban minyak pada sistem ini berupa tegangan sensor optik. Pada penelitian ini, pin A0 merupakan pinout Teensy yang dihubungkan dengan sensor optik.

Kontrol proporsional

Kontrol proporsional digunakan untuk mengatur laju diaphragm pump dengan menghitung selisih antara nilai yang diinginkan (setpoint) dengan nilai hasil pembacaan sensor optik yang telah dikonversi menjadi tegangan, kemudian dikalikan dengan nilai $\mathrm{Kp}$ nya untuk menghasilkan nilai PWM. Nilai PWM diaphragm pump juga dibatasi untuk mengurangi air yang ikut terhisap. Hal ini dikarenakan jika laju diaphragm pump terlalu cepat, maka banyak air yang ikut terhisap. Sedangkan jika terlalu lambat, maka minyak tidak dapat terhisap.

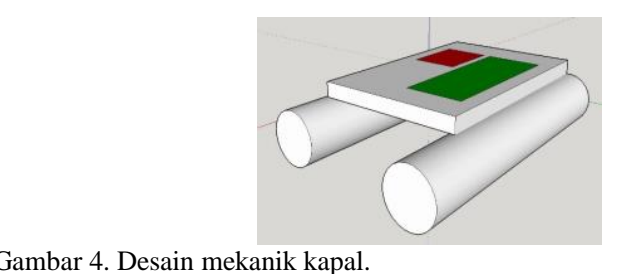

Gambar 4. Desain mekanik kapal.

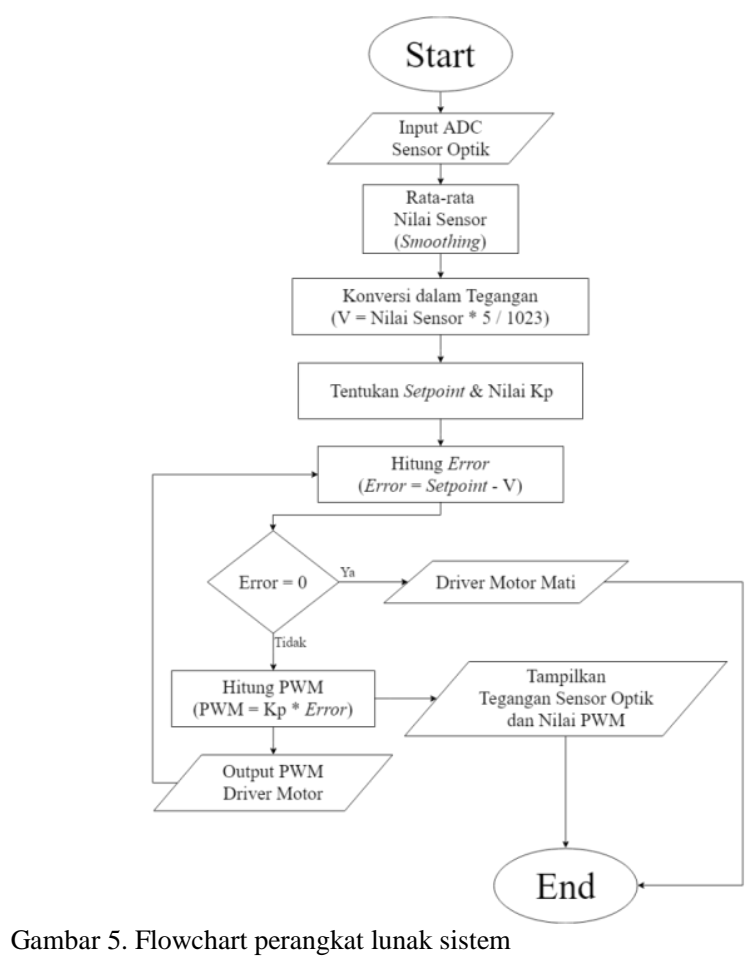

Gambar 5. Flowchart perangkat lunak sistem 


\section{PENGUJIAN DAN ANALISIS SISTEM}

\section{A. Pengujian Diaphragm Pump}

Pengujian diaphragm pump dilakukan untuk mengetahui laju atau daya hisap diaphragm pump dengan nilai PWM yang berbeda-beda. Pada pengujian ini, nilai PWM yang diberikan adalah dari 0 sampai 100 persen. Nilai PWM diatur melalui program yang diunggah ke Teensy. Untuk suplai tegangan, diaphragm pump dihubungkan dengan driver motor yang disuplai dengan sumber tegangan $12 \mathrm{~V}$. Hasil pengujian dapat dilihat pada tabel 1 .

Dari hasil pengujian tersebut, laju atau daya hisap diaphragm pump sesuai dengan spesifikasinya, yaitu sekitar 2 - $3 \mathrm{~L} / \mathrm{min}$ saat diberi tegangan sebesar $12 \mathrm{~V}$. Setelah didapatkan tegangan setpoint, nilai kp dan jenis minyak yang digunakan untuk pengujian sistem ini, maka dilakukan pengujian aktuator yang meliputi driver motor dan diaphragm pump.

Tabel 1.

Hasil pengujian diaphragm pump

\begin{tabular}{cc}
\hline \hline PWM (\%) & Daya Hisap (L/min) \\
\hline 10 & 0 \\
20 & 0 \\
30 & 0.2 \\
40 & 0.5 \\
50 & 0.8 \\
60 & 1.2 \\
70 & 1.5 \\
80 & 1.7 \\
90 & 2.3 \\
100 & 2.8 \\
\hline \hline
\end{tabular}

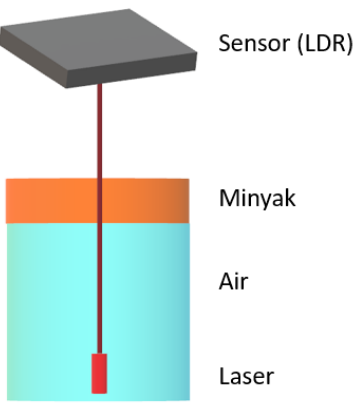

Gambar 6. Metode pengujian minyak.

Dari hasil pengujian menunjukkan bahwa jika diaphragm pump terlalu cepat, maka terdapat banyak air yang ikut terhisap dari akuarium sehingga tangki akan cepat penuh karena terdapat air yang seharusnya tidak ikut dihisap. Sedangkan jika terlalu lambat, minyak tidak dapat terhisap dari permukaan air sesuai dengan pengujian diaphragm pump sebelumnya. Oleh karena itu dilakukan pembatasan rentang kerja diaphragm pump yaitu antara $30-50 \%$ dari nilai PWM saja.

\section{B. Pengujian Minyak Menggunakan Sensor Optik}

Pengujian minyak dilakukan untuk mengetahui pengaruh ketebalan minyak terhadap tegangan sensor optik. Pada pengujian ini, jenis minyak yang digunakan yaitu oli bekas motor dan bahan bakar solar. Pemilihan oli bekas motor karena oli tersebut menyerupai minyak bumi yang memiliki ciri-ciri kental dan berwarna hitam pekat. Sedangkan solar karena merupakan bahan bakar yang digunakan kapal-kapal yang melitasi berbagai perairan. Pengujian dilakukan menggunakan sensor optik yang terdiri dari laser dan LDR seperti yang ditunjukkan pada Gambar 6. Laser berfungsi sebagai sumber cahaya dan LDR akan menerima cahaya tersebut untuk diukur tegangannya. Hasil pengukuran tegangan pada sensor optik ditampilkan pada LCD yang telah diprogram dan diunggah melalui Teensy. Tabel 2 dan Gambar 7 menunjukkan hasil pengujian air tanpa adanya minyak.

Tabel 2 .

Hasil pengujian air menggunakan sensor optik

\begin{tabular}{cc}
\hline \hline Ketebalan $(\mathrm{cm})$ & Tegangan $(\mathrm{V})$ \\
\hline 0 & 4.77 \\
1 & 4.71 \\
2 & 4.71 \\
3 & 4.71 \\
\hline \hline
\end{tabular}

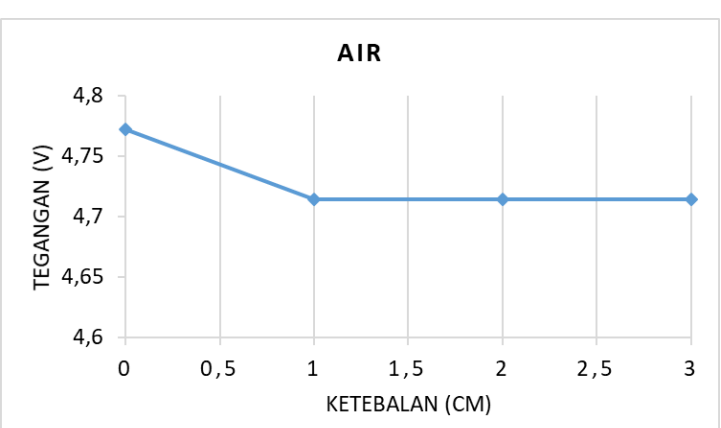

Gambar 7. Hasil pengujian air menggunakan sensor optik.

Tabel 3.

Hasil pengujian oli menggunakan sensor optik

\begin{tabular}{cc}
\hline \hline Ketebalan $(\mathrm{cm})$ & Tegangan $(\mathrm{V})$ \\
\hline 0.5 & 0.04 \\
1 & 0.04 \\
1.5 & 0.03 \\
2 & 0.03 \\
2.5 & 0.03 \\
3 & 0.03 \\
\hline \hline
\end{tabular}

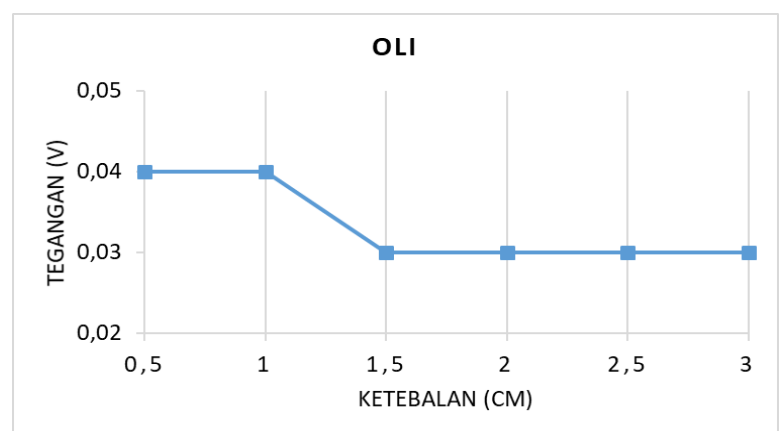

Gambar 8. Hasil pengujian oli menggunakan sensor optik

Ketebalan air tidak terlalu berpengaruh pada tegangan sensor optik. Sesuai dengan penelitian sebelumnya dimana daya serap air terhadap cahaya tergolong kecil, sehingga cahaya laser tidak banyak diserap oleh air [4]. Tabel 3 dan Gambar 8 menunjukkan hasil pengujian oli bekas motor. Berdasarkan pengujian tersebut, ketebalan oli sangat berpengaruh pada tegangan sensor optik. Sesuai dengan penelitian sebelumnya dimana daya serap oli terhadap cahaya tergolong besar, sehingga cahaya laser banyak diserap oleh oli dan cahaya susah menembus lapisan oli [4]. Tabel 4 dan Gambar 9 menunjukkan hasil pengujian bahan bakar solar. Pengaruh solar pada sensor optik tergantung ketebalannya. 
Tabel 4.

Hasil pengujian solar menggunakan sensor optik

\begin{tabular}{cc}
\hline \hline Ketebalan $(\mathrm{cm})$ & Tegangan $(\mathrm{V})$ \\
\hline 0.5 & 4.22 \\
1 & 1.49 \\
1.5 & 0.77 \\
2 & 0.20 \\
2.5 & 0.11 \\
3 & 0.10 \\
\hline \hline
\end{tabular}

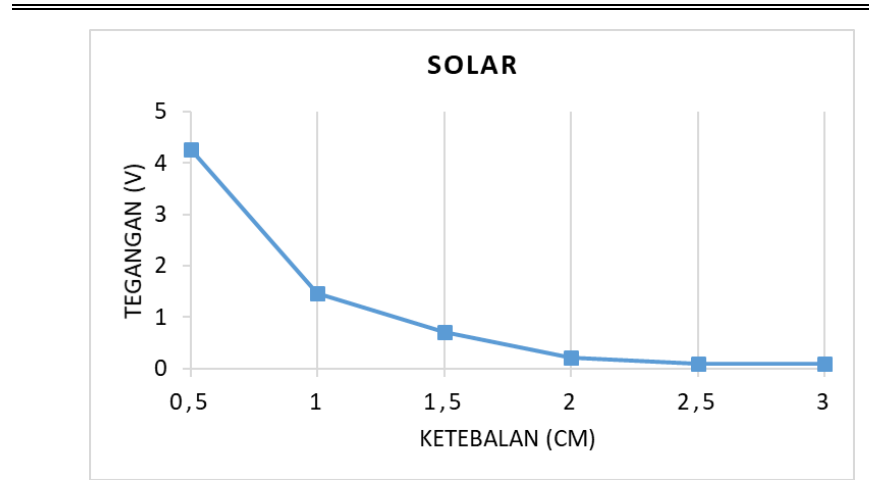

Gambar 9. Hasil pengujian solar menggunakan sensor optik.

Tabel 5.

Perbandingan matematis dan pengujian solar

\begin{tabular}{cccc}
\hline \hline \multirow{2}{*}{ Tegangan $(\mathrm{V})$} & \multicolumn{2}{c}{ Ketebalan $(\mathrm{cm})$} & \multirow{2}{*}{ Error } \\
\cline { 2 - 3 } & Matematis & Pengujian & \\
\hline 4.22 & 0.44 & 0.5 & 0.06 \\
1.49 & 1.06 & 1 & 0.06 \\
0.77 & 1.43 & 1.5 & 0.07 \\
0.20 & 2.26 & 2 & 0.26 \\
0.11 & 2.68 & 2.5 & 0.18 \\
0.10 & 2.68 & 3 & 0.32 \\
\hline \hline
\end{tabular}

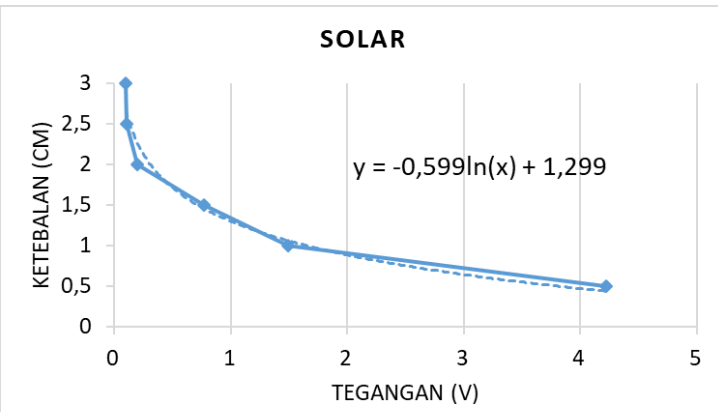

Gambar 10. Pendekatan matematis pada pengujian solar.

Perubahan tegangan terhadap ketebalan solar dapat terlihat dengan baik. Oleh karena itu, minyak yang digunakan pada sistem ini adalah solar. Dari hasil pengujian solar juga dapat dilakukan pendekatan matematis menggunakan persamaan logaritmik untuk memperkirakan ketebalan minyak dari tegangan yang diperoleh sensor optik. Perbandingan hasil pengujian dan pendekatan matematis ditunjukkan pada Gambar 10 dan tabel 5. Dari pendekatan matematis tersebut diperoleh persamaan:

$$
y=-0.599 \ln (x)+1.299
$$

Berdasarkan perbandingan pada tabel 5, perbedaan nilai antara hasil pengujian dan pendekatan matematis tidak terlalu besar. Tingkat kesalahan untuk memperkirakan ketebalan minyak sebesar 15,83\%. Oleh karena itu, sistem dapat memperkirakan ketebalan minyak dari tegangan yang diperoleh sensor optik dengan rentang ketebalan $0.3-2.7 \mathrm{~cm}$.

\section{Pengujian Akhir}

Dari hasil pengujian didapatkan berbagai variabel dan nilai yang akan digunakan pada sistem, seperti tegangan setpoint, nilai $\mathrm{kp}$, jenis minyak yang digunakan dan nilai PWM yang digunakan untuk mengatur laju diaphragm pump. Tabel 6 menunjukkan variabel dan nilai yang akan digunakan pada sistem.

Tabel 6.

Variabel dan nilai yang digunakan pada sistem

\begin{tabular}{ll}
\hline \hline Tegangan Setpoint & $0.3 \mathrm{~cm}$ \\
\hline Nilai Kp & 80 \\
Jenis Minyak & Bahan bakar solar \\
Rentang Nilai PWM & $30-80 \%$ \\
\hline \hline
\end{tabular}

Gambar 11. Hasil pengujian sistem menggunakan ruang pengujian.

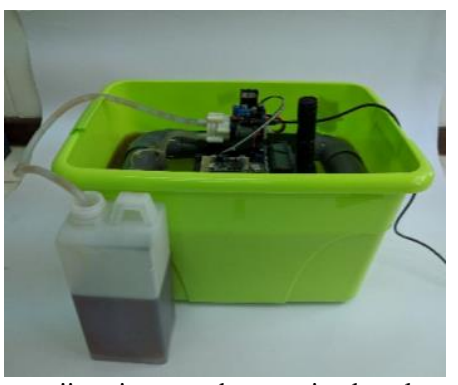

Gambar 12. Hasil pengujian sistem pada prototipe kapal.

Untuk pengujian keseluruhan sistem, ketebalan solar ruang pengujian diberikan sebesar $3 \mathrm{~cm}$. Hasil dari pengujian sistem, sisa lapisan solar pada ruang pengujian sekitar $0.3 \mathrm{~cm}$ seperti yang ditunjukkan pada Gambar 11. Dari hasil tersebut, sistem dapat mengambil minyak setebal $2.7 \mathrm{~cm}$ dari ruang pengujian sehingga tingkat keberhasilan sistem mencapai $90 \%$.

Pengujian selanjutnya yaitu mengimplementasikan sistem pada suatu prototipe kapal. Pada pengujian ini ketebalan awal solar mencapai $1.5 \mathrm{~cm}$. Hasil dari pengujian sistem pada prototipe kapal, sisa lapisan solar sekitar $0.2 \mathrm{~cm}$ seperti yang ditunjukkan pada Gambar 12. Sistem dapat mengambil minyak setebal $1.8 \mathrm{~cm}$, sehingga tingkat keberhasilan implementasi sistem mencapai $86 \%$.

Dari pengujian sistem menggunakan ruang pengujian dan prototipe kapal terdapat perbedaan tingkat keberhasilan sistem yang tidak terlalu jauh, sehingga sistem pemisah air - minyak ini dapat digunakan untuk mengatasi adanya tumpahan minyak di laut. 


\section{KESIMPULAN}

Sistem pemisah air - minyak berbasis metode adsorpsi atau penyedotan ini merupakan suatu metode untuk mengatasi tumpahan minyak di laut secara otomatis. Komponen optik yang memanfaatkan laser dan LDR dapat digunakan untuk mengukur ketebalan minyak dengan jenis bahan bakar solar dibandingkan oli bekas motor. Dengan melakukan pendekatan matematis, ketebalan minyak dapat diperkirakan dari hasil pembacaan sensor optik. Tingkat keberhasilan sistem menggunakan ruang pengujian dan prototipe kapal tidak terlalu jauh, yaitu $90 \%$ menggunakan ruang pengujian dan $86 \%$ pada implementasi prototipe kapal. Dari hasil pengujian tersebut, sistem ini layak untuk diimplementasikan pada ASV (Autonomous Surface Vehicles) sebagai salah satu metode untuk melakukan pembersihan laut dari tumpahan minyak secara otomatis.

\section{DAFTAR PUSTAKA}

[1] A. Utama, "Ratusan Nelayan Balikpapan Terdampak Tumpahan Minyak Menanti Kompensasi," BBC Indonesia, 09-Apr-2018.

[2] S. A. Abdul-Wahab, "In Situ Device for Detection of Oil Spill in Seawater," Electroanalysis, vol. 18, no. 21, pp. 2148-2152, Nov. 2006.
[3] F. R. Saputra and M. Rivai, "Autonomous Surface Vehicle sebagai Alat Pemantau Lingkungan Menggunakan Metode Navigasi Waypoint," Jurnal Teknik ITS, vol. 7, no. 1, Mar. 2018.

[4] S. Oh and M. Lee, "Detection of Hydrocarbon Oil in Seawater by Light Absorption Analysis," SENSORDEVICES 2013: The Fourth International Conference on Sensor Device Technologies and Applications.

[5] P. G. Hewitt, Conceptual Physics. México: Pearson Educación, 2004.

[6] S. Michrandi Nasution, Y. Purwanto, A. Virgono, and G. Chandra Alam, "Integration of Kleptoware as Keyboard Keylogger for Input Recorder Using Teensy USB Development Board," 2014 8th International Conference on Telecommunication Systems Services and Applications (TSSA).

[7] L. Riadhi, M. Rivai, and F. Budiman, "Sistem Pengaturan Oksigen Terlarut Menggunakan Metode Logika Fuzzy Berbasis Mikrokontroler Teensy Board,” Jurnal Teknik ITS, vol. 6, no. 2, 2017.

[8] P. T. Asri, M. Rivai, and T. Tasripan, "Sistem Pendeteksi Kepatahan Mata Bor pada Mesin Cetak PCB Berdasarkan Analisa Getaran Spindle Menggunakan Teensy Board," Jurnal Teknik ITS, vol. 7, no. 1, Mar. 2018

[9] M. Araki, "PID Control," Control Systems, Robotics and Automation, vol. II.

[10] A. Andri Kurniawan, M. Rivai, and F. Budiman, "Sistem Pemandu Pendaratan pada Balon Udara Berbasis Pengolahan Citra dan Kendali PID,” Jurnal Teknik ITS, vol. 5, no. 2, 2016.

[11] P. Dwi Wijaya, M. Rivai, and Tasripan, "Rancang Bangun Mesin Pemotong Styrofoam 3 Axis Menggunakan Hot Cutting Pen dengan Kontrol PID,” Jurnal Teknik ITS, vol. 6, no. 2, 2017. 